\title{
Why African Norms Matter: Subsidiarity and Agency in Peacemaking
}

Obinna F. Ifediora

The University of Queensland

Obinna.ifediora@uq.edu.au

\begin{abstract}
This article explains the problem facing the UN and African regional organizations in applying the principle of subsidiarity in peacemaking. It draws on the concept of norm subsidiarity and examines African norm-setting instruments. It argues that the African Union is a subsidiary actor in the global order, making parallel but distinct norms to export globally, retain autonomy, claim primacy, and deflect implementing uncomfortable external principles. Conversely, African subregional organizations are localizing actors, willing to accept or modify global and regional rules. The significance is that existing studies assume that the AU is or should be a localizing agent, as Chapter VIII of the UN Charter anticipated. Essentially, current studies have subsumed African norms under international rules, denying the importance of African rule-making power. This study shows that African norms underpin subsidiarity and agency in peacemaking and therefore matter. This article contributes to the scholarship on African agency in international relations.
\end{abstract}

Keywords: subsidiarity, norms, agency, subsidiarity, Africa agency, peacemaking 


\section{Introduction}

The UN Charter established the structure of the global order, stressing the Security Council's primary responsibility for peace and security. Chapter VIII of the Charter empowers 'regional agencies and arrangements' to act to maintain international peace and security in line with the UN values and the principle of subsidiarity. ${ }^{1}$ Chapter VIII authority entails that subsidiarity is fixed at the global level, so regional agencies must implement international norms in peacemaking. Such norms include nonimpunity or nonimmunity, established by the Rome Statute of the International Criminal Court (ICC) 1998, and the responsibility to protect (R2P), adopted by the UN General Assembly in 2005 .

Existing studies on Africa's role in R2P and nonimpunity rules in peacemaking assume global norms dominance, subordinate two African norms to international rules, and conceive African regional agencies as localizing actors in the global system. ${ }^{2}$ The two African norms are, 1) the right to protect, as enshrined in article 4(h) of the Constitutive Act of the African Union (AU) 2000, which deals with using military force to protect human rights, and 2) the

\footnotetext{
${ }^{1}$ Norman J. Padelford, 'Regional organization and the United Nations,' International Organization 8:2, 1954, pp. 203-16; Francis O. Wilcox, 'Regionalism and the United Nations,' International Organization 19:3, 1965, pp. 788-811; Haas, Ernst B., 'The United Nations and regionalism,' International Relations 3:10, 1971, pp. 795-815; Andy W. Knight, 'Towards a subsidiarity model for peacemaking and preventive diplomacy: Making Chapter VIII of the UN Charter operational,' Third World Quarterly 17:1, 1996, pp. 31-52; David O'Brien, 'The search for subsidiarity: The UN, African regional organizations and humanitarian action,' International Peacekeeping 7:3, 2000, pp. 57-83.

${ }^{2}$ On R2P, see Tim Murithi, 'The responsibility to protect, as enshrined in article 4 of the Constitutive Act of the African Union,' African Security Studies 16:3, 2007, pp. 14-24; Paul D. Williams, 'The 'responsibility to protect': Norm localisation, and African international society,' Global Responsibility to Protect 1:3, 2009, pp. 392-416; Dan Kuwali, and Frans Viljoen, eds., Africa and the responsibility to protect: Article $4(h)$ of the African Union Constitutive Act (London: Routledge, 2013); Kwesi Aning, and Fiifi Edu-Afful, 'African Agency in R2P: Interventions by African Union and ECOWAS in Mali, Cote D'ivoire, and Libya,' International Studies Review 18:1, 2016, pp. 120-133. On nonimpunity, see Dapo Akande, 'The legal nature of Security Council referrals to the ICC and its impact on Al Bashir's immunities,' Journal of International Criminal Justice 7:2, 2009, pp. 333-352; Adam Bower, 'Contesting the international criminal court: Bashir, Kenyatta, and the status of the nonimpunity norm in world politics, Journal of Global Security Studies, 4:1, 2019, pp. 88-104.
} 
immunity of serving Heads of State and Government, instituted in the Malabo Protocol on the Amendment to the Statute of African Court on Human and People's Rights 2014.

Interestingly, the AU uses both African norms to claim primacy in peacemaking, not to accept global dominance. For example, in Sudan and Kenya, the AU asserted the immunity norm and relied on article 16 of the Rome Statute relating to the deferral of investigation and prosecution to ask the Security Council to suspend the ICC Prosecutor's proceedings against Presidents Omar al-Bashir and Uhuru Kenyetta, respectively. ${ }^{3}$ Similarly, in Libya, the AU rejected the Security Council's use of force to protect human rights outside the right to protect norm and pursued the African-led international mediation, emphasizing African priority. ${ }^{4}$ The AU asserts the primacy of African norms, arguing that the framework for cooperation with the UN in peacemaking 'constitutes a first concrete step towards meeting the priorities of the African Union. ${ }^{5}$ The puzzle is that the AU insists on the precedence of African norms, on the one hand, and acknowledges the Security Council's primary responsibility for international peace and security, and embraces the principle of subsidiarity, on the other hand. ${ }^{6}$ These

\footnotetext{
${ }^{3}$ African Union, Assembly Decision, Assembly/AU/Dec. 493 (XXII). 30-31 January 2014, paras. 6-7.

${ }^{4}$ African Union, Assembly Decision, Assembly/AU/Dec. 385 (XVII), 30 June - 1 July 2011, paras. 3, 7.

5 African Union, Assembly Decision, Assembly/AU/Dec.140 (VIII), 30 January 2007, para. 2. For the broader policy dialogue, see United Nations, General Assembly, A/61/630, annex, 12 December 2006; United Nations, Report of the Secretary-General on the relationship between the United Nations and regional organizations, in particular the African Union, in the maintenance of international peace and security, S/2008/186, April 2008; African Union, Report of the Chairperson of the AU Commission on the partnership between the AU-UN on peace and security: Towards greater strategic and political convergence, PSC/PR/2. (CCCVII), 9 January 2012; African Union, Report of the Chairperson of the AU Commission on the AU-UN partnership: The need for greater coherence, PSC/AHG/3. (CCCXCVII), September 2013; Arthur Boutellis, and Paul D. Williams, Peace operations, the African Union, and the United Nations: Toward more effective partnerships (New York: International Peace Institute, 2013); United Nations, Report of the Secretary-General on strengthening the partnership between the United Nations and the African Union on issues of peace and security in Africa, S/2016/780, 13 September 2016; Cedric de Coning, Linnéa Gelot, and John Karlsrud, eds., The future of African peace operations: From the Janjaweed to Boko Haram (Uppsala; London: Nordiska Afrikainstitutet, 2016), pp. 139-40.

${ }^{6}$ See United Nations, 'Joint United Nations-African Union framework for enhanced partnership in peace and security,' 19 April 2017, <https://unoau.unmissions.org/sites/default/files/signed_joint_framework.pdf>; African Union, 'Report on the proposed recommendations for the institutional reform of the African Union,' 29 January 2017, p. 11, <https://au.int/en/documents/20170129/report-proposed-recommendations-institutional-reformafrican-union>; African Union, Assembly Decision, Assembly/AU/Dec.635(XXVIII), 30-31 January 2017, para. 5; Martin Welz, 'Cooperation and competition: United Nations-African Union relations,' in Stephen Aris, Aglaya Snetkov, and Andreas Wenger, eds. Inter-organizational relations in international security: Cooperation and competition (Oxon: Routledge, 2018), pp. 54-70; Theresa Reinold, The promises and perils of subsidiarity in global governance: Evidence from Africa,' Third World Quarterly 40:11, (2019) pp. 2092-2107.
} 
paradoxical positions by the AU inspired the research question: what explains the AU's understanding of subsidiarity as the priority of African norms in peacemaking?

This article argues that to appreciate the AU's claims to norm priority, we must clarify the concept of regional agency in Chapter VIII, which envisages localizing actors that would implement global norms, including R2P and nonimpunity. However, the AU is a subsidiary actor in the global order. Subsidiary agents make rules and institutions to export globally, retain autonomy, and deal with concerns over foreign domination, so the AU makes parallel but unique norms to claim primacy and deflect implementing uncomfortable foreign rules. The AU accepts partnership if the UN complements African peacemaking efforts with the necessary resources. Unlike the AU, African subregional agencies, like the Economic Community of West African States (ECOWAS) and the Intergovernmental Authority on Development (IGAD) are norm localizing actors, willing to consider, modify, and implement global and regional rules. These agents localize external principles to fit their peacemaking objectives.

The significance of this study is that existing studies assume that the AU is or should be a localizing actor in the global order, but the AU is not a localizing agent and is unlikely to change because African norms demonstrate subsidiarity and agency in the international system. These are the reasons African norms matter. By subordinating African norms to global rules, current scholarships deny Africa's real agency in peacemaking. The conceptual consequence of this study is the contribution toward broadening our knowledge of African agency in international relations. ${ }^{7}$ Studies in the African agency stresses Africa's unique initiatives in all

\footnotetext{
${ }^{7}$ William Brown, 'A question of agency: Africa in international politics,' Third World Quarterly 33:10, 2012, pp. 1889-1908; Karen Smith, 'Africa as an agent of international relations knowledge,' in Scarlett Cornelissen, Fantu Cheru, Timothy M. Shaw, eds., Africa and International Relations in the 21st Century (London: Palgrave Macmillan, 2012), pp. 21-35; Danielle Beswick, and Anne Hammerstad, 'African agency in a changing security environment: Sources, opportunities and challenges,' Conflict, Security and Development 13:5, 2013, pp. 471486; Sophie Harman, and William Brown, 'In from the margins? The changing place of Africa in international relations,' International Affairs 89:1, 2013, pp. 69-87; William Brown, and Sophie Harman, eds., African agency in international politics (Abingdon; England: Routledge, 2013), pp. 1-16; Jo-Ansie van Wyk, 'Africa in
} 
facets of global politics, including in peace and security. The policy implication is that the AU is the international community's essential partner because African norms, particularly the right to protect, can mediate the Security Council's deadlock on R2P. The international community can turn to the right to protect if members of the Security Council exercise the veto power. Moreover, the AU can become a double agent and occasionally apply uncomfortable international rules (see the conclusion for more on this point). Thus, the African partners must become more persuasive about the merits of global principles. Then subsidiarity becomes progressively pragmatic rather than predetermined at the global level. In this sense, the article injects fresh thinking about how the AU may sometimes serve as the international community's agent and apply global rules in peacemaking.

This study implements conceptual and qualitative analysis methods. It adopts Amitav Archaya's norm subsidiarity concept to understand African agency in the global order ${ }^{8}$ and utilizes content analysis ${ }^{9}$ to examine African norm-setting instruments. The examination focuses on two critical African norms, 1) the serving Heads of State and Government immunity and 2) the right to protect. Also, the analysis draws on decisions and communiqués of the AU principal organs, such as the Assembly and the Peace and Security Council.

The article has two main sections: the first defines the principle of subsidiarity and the problems with applying it and discusses the differences between subsidiary and localizing actors in the international order. It clarifies the concept of regional agency in Chapter VIII. The second explores African agencies. The AU norm-making actions show it is a subsidiary actor.

international relations: Agent, bystander or victim?' in Paul-Henri Bischoff, Kwesi Aning, and Amitav Acharya, eds., Africa in global international relations: Emerging approaches to theory and practice (Oxon: Routledge, 2016), pp. 108-120; Lesley Blaauw, 'African agency in international relations: Challenging great power politics?' in Bischoff, Aning, and Acharya, Africa in global international relations, pp. 85-107.

${ }^{8}$ Amitav Acharya, 'Norm subsidiarity and regional orders: Sovereignty, regionalism, and rule-making in the Third World,' International Studies Quarterly 55:1, 2011, pp. 95-123; Amitav Acharya, 'How ideas spread: Whose norms matter? Norm localization and institutional change in Asian regionalism,' International Organization 58:2, 2004, pp. 239-275.

${ }^{9}$ Margaret Hermann, 'Content analysis,' in Audie Klotz and Deepa Prakash, Qualitative methods in international relations: A pluralist guide (London: Palgrave Macmillan, 2008), pp. 151-67. 
Using ECOWAS and IGAD as examples, the section illustrates that subregional organizations are localizing agents. The conclusion considers the implications for knowledge and policy.

\section{Subsidiarity and Agency in the Global Order}

The principle of subsidiarity is easy to understand. For instance, the Oxford English Dictionary defines subsidiarity as 'the principle that a central authority should have a subsidiary function, performing only those tasks which cannot be performed at a more intermediate or local level.' Similarly, the Cambridge English Dictionary defines subsidiarity as 'the principle that decisions should always be taken at the lowest possible level or closest to where they will have their effect, for example in a local area rather than for a whole country.' In essence, subsidiarity involves empowering or recognizing the competence of a weaker or less powerful actor in a complex governance system. Despite subsidiarity's apparent purpose, the application of the principle is not so evident. As Ann-Marie Slaughter put it:

[Subsidiarity] is a principle of locating governance at the lowest possible level - that closest to the individuals and groups affected by the rules and decisions adopted and enforced. Whether this level is local, regional, national, or supranational is an empirical question, dictated by considerations of practicability rather than a preordained distribution of power. ${ }^{10}$

Indeed, the application of subsidiarity is often controversial and requires extensive negotiation.

Several studies have explored the uses of subsidiarity in different contexts and the various interpretations of the principle. ${ }^{11}$ In particular, Kees van Kersbergen and Bertjan Verbeek

\footnotetext{
${ }^{10}$ Anne-Marie Slaughter, A new world order (Princeton: Princeton University Press, 2009), p. 30.

${ }^{11}$ For a helpful survey of the history, interpretations, and uses of subsidiarity, see John F. Kenney, 'The principle of subsidiarity,' The American Catholic Sociological Review 16:1, 1955, pp. 31-6; Andrew Murray, 'The principle of subsidiarity and the Church,' The Australian Catholic Record 72:2, 1995, pp. 163-72; Andreas Follesdal, 'Subsidiarity,' Journal of Political Philosophy 6:2, 1998, pp. 190-218; Michelle Evans, and Augusto Zimmermann, eds., Global perspectives on subsidiarity (New York: Springer, 2014).
} 
studied subsidiarity in Europe as a norm undergoing contestation and refinement after its adoption at the Maastricht summit. ${ }^{12}$ The point is that the practice of subsidiarity is complex.

The purpose of this section is to understand subsidiarity in the global order, as represented in the UN Charter, which governs relations between the UN and regional organizations and stresses the Security Council's primary responsibility for maintaining international peace and security. ${ }^{13}$ Essentially, the UN Charter predetermined subsidiarity at the global scale by stressing the Security Council's primacy. So, the vital interest in examining Chapter VIII, which deals with the role of 'regional arrangements and agencies' in maintaining global peace and security, is clarifying the idea of a regional agency, in the sense of determining the type of agent the provision envisioned. To understand agent types and characteristics and accurately interpret regional agency in the international order, the concepts of norm subsidiarity and localization are extremely helpful.

Amitav Acharya's concepts of norm localization and subsidiarity explain actors' agency in norm emergence and evolution. First, the localization framework explains the interaction between local actors and norms in the global system. The model describes how such agents engage with, accept, or refine external norms and institutions. It involves 'the active construction (through discourse, framing, grafting and cultural selection) of foreign ideas by local actors, which results in the former developing significant congruence with local beliefs and practices.' Crucially, the localization process can lead to changes to the institutional design of the localizing actor or the creation of 'new institutions mimicking existing institutional design.' Also noteworthy is that localization can 'settle most cases of normative contestation'

\footnotetext{
${ }^{12}$ Kees van Kersbergen, and Bertjan Verbeek, 'The politics of international norms: Subsidiarity and the imperfect competence regime of the European Union,' European Journal of International Relations 13:2, 2007, pp. 217 238.

${ }^{13}$ Padelford, 'Regional organization and the United Nations'; Wilcox, 'Regionalism and the United Nations'; Knight, 'Towards a subsidiarity model for peacemaking and preventive diplomacy'; O'Brien, 'The search for subsidiarity.'
} 
through the adaption, by local actors, of foreign norms. Significantly, such local actors rarely produce rules or institutions contradicting or contesting external norms or institutions. Instead, localizing agents strive to 'strengthen, not replace, existing institutions' and accept ideas and programs that promote their goals, 'without fundamentally altering existing social identity.' Finally, local actors who engage in the 'wholesale' localization process accept foreign norms and institutions without any modification. ${ }^{14}$

Second, unlike norm localization, norm subsidiarity is 'a process whereby local actors create rules with a view to preserve their autonomy from dominance, neglect, violation, or abuse by more powerful central actors.' In other words, it involves how local agents produce norms, rules, and institutions to counter foreign ideas and preserve their independence because they fear control by external actors. Importantly, norm subsidiarity is primarily concerned with 'relations between local actors and external powers, in terms of the former's fear of domination by the latter.' Regional powers, orders, actors, or agents, like the EU and the AU, are more likely to engage in norm subsidiarity. As this article argues, African immunity and the right to protect norms are subsidiary norms, demonstrating that the AU is a subsidiary agent, not a localizing actor in the international system.

\footnotetext{
${ }^{14}$ Acharya, 'How ideas spread,' pp. 239-254. See also Amitav Acharya, Whose ideas matter? Agency and power in Asian regionalism (Ithaca; London: Cornell University Press, 2009). For a helpful examination of norm evolution and contestation in international politics, see Martha Finnemore, and Kathryn Sikkink, 'International norm dynamics and political change,' International Organization 52:4, 1998, pp. 887-917; Antje Wiener, Contestation and constitution of norms in global international relations (Cambridge: Cambridge University Press, 2018). For studies on localization and African regional organizations, see Paul D. Williams, 'From non-intervention to non-indifference: The origins and development of the African Union's security culture,' African Affairs 106:423, 2007, pp. 253-279; Aarie Glas, 'African Union security culture in practice: African problems and African solutions,' International Affairs 94:5, 2018, pp. 1121-1138; Aarie Glas, and Emmanuel Balogun, 'Norms in practice: People-centric governance in ASEAN and ECOWAS,' International Affairs, 96:4, 2020, pp. 1015-32. For some insightful critiques, see David Capie, 'Localization as resistance: The contested diffusion of small arms norms in Southeast Asia,' Security Dialogue 39:6, 2008, pp. 637-658; Daisuke Minami, 'Lost in translation: Problematizing the localization of transnational activism,' European Journal of International Relations 25:2, 2019, pp. 511-537; Lisbeth Zimmermann, 'Same same or different? Norm diffusion between resistance, compliance, and localization in post-conflict states,' International Studies Perspectives 17:1, 2016, pp. 98-115; Lisbeth Zimmermann, 'More for less: The interactive translation of global norms in postconflict Guatemala,' International Studies Quarterly 61:4, 2017, pp. 774-785.
} 
Notably, an agent may engage in norm localizing and subsidiary behaviour and become 'complementary' or 'run in tandem.' ${ }^{15}$ Or otherwise, become a double agent in the global order, in the sense of implementing foreign rules and creating subsidiary norms. Table I provides a visual summary of three significant behavioural differences between subsidiary and localizing actors in the global order to ease our understanding.

Table I. Behavioural Differences between Subsidiary and Localizing Agents

\begin{tabular}{|c|c|}
\hline Subsidiary Agents & Localizing Agents \\
\hline Develop local norms and institutions & $\begin{array}{c}\text { Accept and modify external norms and } \\
\text { institutions }\end{array}$ \\
\hline Reject external norms and institutions & Take external norms and institutions \\
\hline Export local norms and institutions & Import external norms and institutions \\
\hline
\end{tabular}

\section{Clarifying Regional Agency}

Applying the concepts of norm subsidiarity and localization to the UN-led global order helps determine the type of agent the system anticipated to assist the Security Council in maintaining international peace and security. For clarity, Chapter VIII of the UN Charter authorizes 'regional arrangements and agencies,' such as the EU, the AU, ECOWAS, and IGAD, to undertake 'appropriate regional action' that is 'consistent with the principles and purposes of the United Nations.' Scholars like Norman Padelford, Francis Wilcox, and Ronald Yalem have indicated that subsidiarity in the global order refers to the role of regional

\footnotetext{
${ }^{15}$ Acharya, 'Norm subsidiarity and regional orders,' pp. 97-9. The emphasis is in the original text.
} 
organizations in advancing the Security Council's mandate to sustain global stability. ${ }^{16}$ The presumption is that regional organizations are localizing agents of the UN and would implement global norms and rules designed to maintain and support international order. The assumption underscores the realization that the universalism in peace and security management embedded in Chapter VII of the UN Charter and invested in the Security Council may be insufficient in tackling myriad threats to the world order.

The Cold War rendered subsidiarity in the context of regionalism redundant. Still, the UN Secretary-General, Boutros Boutros-Ghali, revived the vision in the 1992 ground-breaking report on making global security governance through the Security Council more efficient. Boutros-Ghali placed regional organizations at the core of international security strategy for the post-Cold War global environment, stressing that:

regional arrangements or agencies in many cases possess a potential that should be utilized in serving the functions covered in this report: preventive diplomacy, peace-keeping, peacemaking and post-conflict peacebuilding. Under the Charter, the Security Council has and will continue to have primary responsibility for maintaining international peace and security. ${ }^{17}$

Invariably, regional organizations are essential agents of the Security Council, contributing to creating 'a new global order' and addressing the post-Cold War's 'global disorder.' ${ }^{18}$ The

\footnotetext{
${ }^{16}$ Padelford, 'Regional organization and the United Nations,'; Wilcox, 'Regionalism and the United Nations.' In particular, Ronald Yalem focuses on explaining the implications of rising regional organizations for the stability or instability of the international system, Ronald J. Yalem, 'Regionalism and world order,' International Affairs 38:4, 1962, pp. 460-471.

${ }^{17}$ United Nations, An agenda for peace: Preventive diplomacy, peacemaking and peace-keeping,' Report of the Secretary-General pursuant to the statement adopted by the Summit Meeting of the Security Council, A/47/277 S/24111, 17 June 1992, para. 64.

${ }^{18}$ David B. Dewitt, David G. Haglund, and John J. Kirton, eds., Building a new global order: Emerging trends in international security (Toronto; New York: Oxford University Press, 1993); Knight, 'Towards a subsidiarity model for peacemaking and preventive diplomacy,' p. 45; O'Brien, 'The search for subsidiarity.' For a useful analysis of the post-Cold War global security architecture, see Barry Buzan, and Ole Wæver, Regions and powers: The structure of international security (Cambridge: Cambridge University Press, 2003). For a discussion of the African perspective in the new global system, see Christopher Clapham, Africa and the international system: The politics of state survival (Cambridge: Cambridge University Press, 1996), chap. 2.
} 
consensus is that measures for maintaining international security must centre in the regions without qualifying the Security Council's primacy in peacemaking.

From the UN's perspective, partnership and cooperation in peacemaking with regional organizations entail control or, as the Security Council stated, 'the requirement for oversight by the Security Council for operations authorized by the Security Council and under the Security Council's authority consistent with Chapter VIII of the Charter. ${ }^{19}$ In essence, the Security Council's dominance is inherent in the structure of the international order - a system that stresses power and the preponderance of influential actors' norms and rules and obscures and marginalizes the rules and norms of weaker actors, such as African regional organizations and states. ${ }^{20}$ Notably, the UN-based international order is hierarchical and subordinative, so the meaning of subsidiarity contrasts with the more general understandings, including the definitions discussed above. ${ }^{21}$ Here, actors' agency is relevant to the extent that it serves the UN principles and values. In other words, the concept of regional agency in Chapter VIII is about localizing global norms and rules.

The Agency Scholarship Response

Scholarship on agency in international relations emphasizes different forms of power and underlines less powerful actors' ability to cause or contribute to systemic or structural

\footnotetext{
${ }^{19}$ United Nations, Security Council Resolution, S/RES/2320 (2016), 8 November 2016, para. 6.

20 William I. Zartman, 'Africa as a subordinate state system in international relations,' International Organization 21:3, 1967, pp. 545-564; Kennet N. Waltz, Theory of international politics (New York: McGraw Hill, 1979); Hans J. Morgenthau, Politics among nations: The struggle for power and peace (New York: Alfred Knopf, 1985); Ian Taylor, and Paul Williams, eds., Africa in international politics (Oxon: Routledge, 2004).

${ }^{21}$ In Europe, for example, the purpose of subsidiarity is to constrain the EU's power over the Member States' concerns about domination, see Nicholas Emiliou, "Subsidiarity: An effective barrier against 'the enterprises of ambition'?" European Law Review 17:5, 1992, pp. 383-407, p. 384; Kees van Kersbergen, and Bertjan Verbeek, 'The politics of subsidiarity in the European Union,' Journal of Common Market Studies 32:2, 1994, pp. 215-36, p 216; Alain Delcamp, Definition and limits of the principle of subsidiarity: Report prepared for the steering committee on local and regional authorities (Strasbourg: Council of Europe Press, 1994), p. 24; Christoph Henkel, The allocation of powers in the European Union: A closer look at the principle of subsidiary,' Berkeley Journal of International Law 20, 2002, pp. 359-85, p. 360; Kersbergen, and Verbeek, 'The politics of international norms.'
} 
change. ${ }^{22}$ From this viewpoint, scholarship on African agency in global politics stresses African states' and organizations' capabilities despite international structures constraining or obscuring their actions. As William Brown described the research agenda, the African agency facilitates the engagement with the "narratives of Africa that present the entire continent as perpetual victim and lacking political initiatives.' Equally, Danielle Beswick and Anne Hammerstad explained that African agency involves the 'assumption of African actors wielding real agency - making decisions based on their own imaginations and perceptions of aims and interests.' As this article argues, Africa's 'real agency' is evident in African norms that serve the African concerns and objectives. Equally, Brenden Vickers' essay underpins the empirical angle, demonstrating that 'African countries are no longer passive players in international relations' because 'African Group has been far more active and assertive' in multilateral negotiations on security governance. ${ }^{23}$ This understanding of agency informs this article's analysis of African norm-setting instruments and policy documents to highlight why African norms matter and explain the AU's interpretation of subsidiarity and the problem facing the UN and African regional agencies in applying the principle in peacemaking.

\section{Understanding African Agencies}

This section implements the concepts of norm subsidiarity and localization to study African norm-setting instruments and translate African agencies in peacemaking in the international order. It comprises two subsections: the first component applies norm subsidiarity and shows that the AU is a subsidiary agent whose parallel but unique norms maintain Africa's autonomy

\footnotetext{
${ }^{22}$ Alexander Wendt, Social theory of international politics (Cambridge: Cambridge University Press, 1999); Michael Barnett, and Raymond Duvall, 'Power in international politics,' International Organization 59:1, 2005, pp. 39-75; Martin Hollis, and Steve Smith, 'Two stories about structure and agency,' Review of International Studies 20:3, 1994, pp. 241-251.

${ }^{23}$ Brown, 'A question of agency,' p. 1904; Beswick and Hammerstad, 'African agency in a changing security environment,' p. 480; Brenden Vickers, 'Africa and the rising powers: Bargaining for the 'marginalized many', International Affairs 89:3, 2013, pp. 673-693, p. 673.
} 
and priority and deflect external norms in peacemaking. The second segment operationalizes norm localization to demonstrate that subregional agencies, such as ECOWAS and IGAD, are localizing actors willing to accept and modify global and regional norms.

This article's focus on the analysis of norm-setting instruments will explain the seemingly paradoxical positions adopted by the AU in interpreting and applying subsidiarity in peacemaking. The puzzle has been reflected in empirical studies seeking to understand the complexity associated with applying subsidiarity in peacemaking in Africa. For instance, Laurie Nathan observed that:

The African Union's position is contradictory, promoting subsidiarity in terms of AU-UN relations, but not in terms of AU-REC relations, whereas the United Nations has an ambivalent stance, content to support the maxim of "African solutions to African problems" unless a particular conflict is of great concern to the UNSC, in which case the primacy of the Council prevails. It is only the RECs that wholeheartedly endorse the principle. ${ }^{24}$

This article's focus on norm-making clarifies these apparent inconsistencies. Other notable studies, like Bjørn Møller, examined the problem from the inter-African organizational dispute perspective, concluding that the African regional organization must change the entire continent's security structure to create a seamless framework for interaction and order in peacemaking. Likewise, Michelle Ndiaye explored the issue and underlined establishing a 'diverse and less hierarchical approach' to applying subsidiarity. ${ }^{25}$ The analysis below centres on normative behaviour for the explanation of subsidiarity and agency in peacemaking.

\footnotetext{
${ }^{24}$ Laurie Nathan, 'Will the lowest be first? Subsidiarity in peacemaking in Africa,' in Pamela Aall and Chester Crocker A., eds., Minding the gap: African conflict management in a time of change (Waterloo: Centre for International Governance Innovation, 2016), pp. 157-70, pp. 166-7.

25 Bjørn Møller, Africa's sub-regional organisations: Seamless web or patchwork? (London: Crisis States Research Centre, London School of Economics and Political Science, 2009), p. 18; Michell Ndiaye, 'The relationship between the AU and the RECs/RMs in relation to peace and security in Africa: Subsidiarity and inevitable common destiny,' In De Coning, Gelot, and Karlsrud, The future of African peace operations, pp. 52-
} 
The AU is Africa's premier regional organization. It occupies a unique position in the global order, bestriding the UN and eight African subregional organizations known as Regional Economic Communities (RECs) and two Regional Mechanisms for Conflict Prevention, Management and Resolution (RMs). ${ }^{26}$ This prime position carries the dual responsibility for developing African norms through norm-setting instruments and frameworks to coordinate the RECs' policies and asserting and defending such policies in Africa's relations with the international community, including the UN.

This analysis demonstrates that the AU has adopted instruments creating the subsidiary norms of immunity and the right to protect and policies asserting these norms in peacemaking. It shows that both norms are designed to advance Africa's unique interests and concerns, different from the UN's goals. Specifically, the AU has subsidiarized the norm of the 'right of intervention' or what this article describes as the right to protect in article 4(h) of the Constitutive Act and rejected the R2P principle. Also, the AU has made the rule of immunity for serving Heads of State and Government in the Malabo Protocol contrasting with the international norm on nonimpunity provided in the Rome Statute. Both African norms are different from their international counterparts, which establishes the AU as a subsidiary actor

64. See also Bjørn Møller, The pros and cons of subsidiarity: The role of African regional and subregional organisations in ensuring peace and security in Africa (Copenhagen: DIIS, 2005); Darkwa, 'The strategic relationship between the African Union and its partners,' in De Coning, Gelot, and Karlsrud, The future of African peace operations, 65-75; Laurie Nathan, 'How to manage interorganizational disputes over mediation in Africa,' Global Governance 23:2, 2017, pp. 151-162.

${ }^{26}$ The RECs are the Arab Maghreb Union, the Community of Sahel-Saharan States, the Common Market for Eastern and Southern Africa, the East African Community, the Economic Community of Central African States, the Economic Community of West African States, the Inter-Governmental Authority on Development, and the Southern African Development Community. The RMs are the East Africa Standby Brigade Coordination Mechanism, and the North Africa Regional Capability, see African Union, Memorandum of understanding on cooperation in the area of peace and security between the African Union, the Regional Economic Communities, and the Coordinating Mechanisms of the Regional Standby Brigades Eastern Africa and Northern Africa (Addis Ababa: African Union Commission, 2008), hereafter refer to as the Memorandum of Understanding. 
and demonstrates African agency in peacemaking. Significantly, the right to protect and the Heads of State and Government immunity underpin the norm subsidiary, not norm localization, behaviour, and characterize African agency in the global order.

Africa's norm-setting instruments are organized under what the AU Assembly ${ }^{27}$ described as 'a Pan-African Architecture on Governance' based on 'African Shared Values. ${ }^{28}$ The Assembly defined African Shared Values as 'democratic governance, popular participation, the rule of law, human and peoples' rights and sustainable socioeconomic development.' The objectives are to ensure 'greater synergy between peace and security matters and governance and democracy, [and] that developments in the terrain of shared values feature prominently in the Peace and Security Council' ${ }^{29}$ deliberations on peace and security interventions.

The Pan-African Architecture on Governance (AGA) has three pillars: 1) the normsetting instruments, such as the Constitutive Act, the Protocol Establishing the Peace and Security Council, Protocol on the Amendment to the African Court on Human and People's Rights, the African Model Anti-Terrorism Law, the Lomé Declaration for an OAU Response to Unconstitutional Changes of Government, and the African Charter on Democracy, Elections, and Governance; 2) the norm implementing institutions, including the Assembly, the Peace and Security Council, the African Union Commission, the RECs, the African Court, the African Commission on Human and People's Rights, the African Peer Review Mechanism, the New Partnership for Africa's Development, Planning and Coordinating Agency; and 3) the norm interaction mechanisms, like the African Governance Platform involving civil society groups, non-governmental organizations, and youth groups. AGA has five tangible clusters, 1)

\footnotetext{
${ }^{27}$ The Assembly is the highest decision-making organ in the AU system and comprises all the Heads of State and Government of the 55 Member States.

${ }^{28}$ African Union, Assembly Decision, Assembly/AU/Dec.304(XV), 27 July 2010, para. 1.

${ }^{29}$ African Union, Assembly Declaration, Assembly/AU/Decl. 1(XVI), 30-31 January 2011, para. 4.
} 
democracy, 2) human rights and transitional justice, 3) governance, 4) constitutionalism and the rule of law, and 5) humanitarian affairs.

In addition, the Protocol establishing the Peace and Security Council (the Protocol) 2002 identified five central norm implementing institutions: The Peace and Security Council, the AU organ in charge of the day-to-day responses to threats to regional peace and security, the AU Commission; the African Standby Force; the Peace Fund; the Panel of the Wise; and the Continental Early Warning System. These institutions, including the RECs, are broadly called African Peace and Security Architecture (APSA), the dynamic, continent-wide blueprint for peacemaking. ${ }^{30}$

Article 16 of the Protocol established the primacy of the AU over peace and security matters, and article 7 mandates the Peace and Security Council and the Commission to 'develop policies and action required to ensure that any external initiative in the field of peace and security on the continent takes place within the framework of the Union's objectives and priorities.' These provisions empower the AU to create rules subordinating foreign norms and rules and clarify the Assembly's decision that the initial framework on relations with the UN 'constitutes a first concrete step towards meeting the priorities of the African Union.' Significantly, the institutional mandate and the Assembly's action demonstrate a claim to the primacy of African norms peacemaking, portraying the AU as a subsidiary actor.

\footnotetext{
${ }^{30}$ For more discussion on APSA, see Stephan Kingebiel, 'Africa's new peace and security architecture: Converging the roles of external actors and African interests,' African Security Studies 14:2, 2005, pp. 35-44; David J. Francis, Uniting Africa: Building regional peace and security systems (London: Routledge, 2006); Ulf Engel, and João Gomes Porto, eds. Africa's new peace and security architecture: Promoting norms, institutionalizing solutions (London: Ashgate, 2010), pp. 1-12; Alex Vines, 'A decade of African peace and security architecture,' International Affairs 89:1, 2013, pp. 89-109.

${ }^{31}$ African Union, Assembly Decision, Assembly/AU/Dec.140 (VIII), 2007, para. 2.
} 
Specifically, article 17 of the Protocol addresses relations with the UN. It acknowledges the Security Council's 'primary responsibility for the maintenance of international peace and security,' and provides that:

Where necessary, recourse will be made to the United Nations to provide the necessary financial, logistical and military support for the African Unions' activities in the promotion and maintenance of peace, security and stability in Africa, in keeping with the provisions of Chapter VIII of the UN Charter on the role of Regional Organizations in the maintenance of international peace and security.

This provision shows that the AU envisages a complementary partnership where the UN supplies resources advancing African 'priorities' in the context of peacemaking or maintaining international peace and security. ${ }^{32}$ In essence, article 17 illuminates the AU's interpretation of 'cooperation based on complementarity' in the latest framework for partnership with the UN, ${ }^{33}$ which is that the UN complements or supports Africa's priorities. The AU policy actions subordinate international rules to African norms. Notably, the Assembly does not contest the Security Council's primary responsibility for international peace and security, but it does assert the primacy of African norms in peacemaking, demonstrating norm subsidiarity.

The Peace and Security Council have further developed the concept of complementarity in the common African position on the review of peace operations, adding that 'partnership on the basis of division of labour' is the guiding principle of subsidiarity. The Council underscored African 'priority-setting,' noting that the AU and the UN 'need to engage in dialogue to

\footnotetext{
${ }^{32}$ For more details on the African Union's interpretation of partnership with the United Nations, see African Union, 'Report of the Chairperson of the AU Commission on the partnership between the AU-UN on peace and security: Towards greater strategic and political convergence, PSC/PR/2. (CCCVII), 9 January 2012; African Union, 'Report of the Chairperson of the AU Commission on the AU-UN partnership: The need for greater coherence, PSC/AHG/3. (CCCXCVII), September 2013.

${ }^{33}$ United Nations, 'Joint United Nations-African Union framework for enhanced partnership in peace and security,' p.1
} 
establish a mutually agreed division of labor to foster coherence and limit competition. ${ }^{34}$ The outcome of that dialogue is the current framework for partnership, which observed that 'the United Nations and African Union recognize that their efforts must be combined in a complementary and mutually-reinforcing manner [and] a clear division of labour and consultation are essential for implementation. ${ }^{35}$ Importantly, the Peace and Security Council interprets 'division of labour' as reinforcing African priorities, as 'The AU has a very limited in-house capacity to support its own missions and will therefore have to rely on outsourcing and partnerships. ${ }^{36}$ Pertinently, the AU policy behaviour indicates no intention of following international norms, and the $\mathrm{AU}$ has consistently pursued African priorities, exhibiting subsidiary agency in the global order.

Two significant norm-setting actions by the AU provide concrete evidence of norm subsidiarity and subsidiary agency in the international order. These are 1) the Malabo Protocol establishing the Heads of State and Government immunity and 2) the Constitutive Act creating the right to protect as enshrined in article 4(h). These norm-setting instruments parallel UN norm-making mechanisms, but the purpose of the norms they created are substantially different.

\section{The Immunity Norm}

The Assembly adopted the Protocol on the Amendment to the Statute of African Court of Justice and Human Rights (the Malabo Protocol) in 2014, creating immunity for serving

\footnotetext{
${ }^{34}$ African Union, Common African Position on the UN review of peace operations, PSC/PR/2(DII), 29 April 2015, para. 6. For a helpful discussion of African common positions as agency, see Siphamandla Zondi, 'Common positions as African agency in international negotiations: An appraisal,' in Brown and Harman, African agency in international politics, pp. 33-47.

${ }^{35}$ United Nations, 'Joint United Nations-African Union framework for enhanced partnership in peace and security,' p. 3.

${ }^{36}$ African Union, Common African Position on the UN Review of Peace Operations, para. 25.
} 
African Heads of State and Government. The Malabo Protocol is not yet in force, as it awaits ratification by the 15 Member States' signatories. Pertinently, article 46 provides that:

No charges shall be commenced or continued before the Court against any serving AU Head of State and Government, or anybody acting or entitled to act in such capacity, other senior state officials based on their functions, during their tenure of office.

The Malabo Protocol parallels the Rome Statute to the extent that both Statutes broadly seek to prevent core crimes, such as genocide and aggression, war crimes, and crimes against humanity. The notable difference is that article 27 of the Rome Statute states that:

This Statute shall apply equally to all persons without any distinction based on official capacity. In particular, official capacity as a Head of State or Government, a member of a Government or parliament, an elected representative or a government official shall in no case exempt a person from criminal responsibility under this Statute, nor shall it, in and of itself, constitute a ground for reduction of sentence.

Both Statutes have similar objectives but contrasting rules, and in this sense, the African immunity norm for serving senior officials demonstrates subsidiary, not localizing, policy behaviour. $^{37}$

Significantly, the Peace and Security Council created the immunity because of Africa's fear of the UN Security Council's domination and the ICC prosecution that jeopardizes transitional administrations in societies emerging from war and violent conflict. The immunity norm is derived from the international customary law but has generated robust academic

\footnotetext{
${ }^{37}$ For a helpful discussion of the difficult relations between the ICC and the AU in the context of norm contestation, see Bower, 'Contesting the international criminal court.'
} 
exchange. ${ }^{38}$ Nevertheless, the Peace and Council expect the UN Security Council's cooperation in implementing the norm, arguing that:

The UN should support the AU in the latter's efforts to articulate more fully the intersection and prioritising of peace, justice and reconciliation as it obtains on the African Continent, and should view the AU's efforts as a contribution to the global search for principled responses to the challenges of the new conflicts the world faces. The UN should support the AU's efforts to enhance its capacity to prosecute and adjudicate serious crimes. The UNSC should treat with the seriousness they deserve the AU's decisions and requests to defer cases before the ICC in order to ensure that peace efforts are not undermined. ${ }^{39}$

Here, the Council claims priority of the subsidiary norm of immunity for sitting senior officials amidst the ICC prosecution of President of Sudan, Omar al-Bashir, President of Kenya, Uhuru Kenyatta, and Kenya's Deputy President, William Ruto. Pertinently, Africa's subsidiary norm prioritizes peace, an idea the AU Commission managed to insert in the new framework for partnership with the UN in the following language: 'Cooperation in response to conflict will be based on agreed principles, including the primacy of political solutions. ${ }^{40}$

In sum, the AU normative actions, creating and advancing the African norm on immunity underscore subsidiary agency in the international system, not a localizing agency which may lead to the localization of global rule on transitional justice. The African norm on immunity matters because it elucidates the African agency, particularly the AU, in international

\footnotetext{
${ }^{38}$ Steffen Wirth, 'Immunity for core crimes? The ICJ's judgment in the Congo v. Belgium Case,' European Journal of International Law 13:4, 2002, pp. 877-893; Akande, 'The legal nature of Security Council referrals to the ICC and its impact on Al Bashir's immunities'; Paola Gaeta, Paola, 'Does President Al Bashir enjoy immunity from arrest?' Journal of International Criminal Justice 7:2, 2009, pp. 315-332; Dapo Akande, and Sangeeta Shah, 'Immunities of state officials, international crimes, and foreign domestic courts,' European Journal of International Law 21:4, 2010, pp. 815-852.

${ }^{39}$ African Union, Common African position on the UN Review of peace operations, para. 28.

40 United Nations, 'Joint United Nations-African Union framework for enhanced partnership in peace and security,' p. 5.
} 
politics (see the concluding segment below for what this means for knowledge, as well as policy).

The Right to Protect Norm

The Organization of African Unity (OAU), the predecessor to the AU, adopted the Constitutive Act of the AU in 2000. Article 4(h) establishes 'The right of the Union to intervene in a Member State pursuant to a decision of the Assembly in respect of grave circumstances, namely: war crimes, genocide and crimes against humanity.' Scholars have interpreted article 4(h) as a substantial, distinct normative action for human rights protection. ${ }^{41}$ The normative significance is that 'the right to intervene' or right to protect is a subsidiary norm on the use of force in the global system that reinforces the AU's claims to the primacy of African norms. As the recommendation of the International Panel of Eminent Personalities that the OAU commissioned to study the global failure to prevent the Rwandan genocide and propose means to avoiding future occurrences put it:

Since Africa recognizes its own primary responsibility to protect the lives of its citizens, we call on: a) the OAU to establish appropriate structures to enable it to respond effectively to enforce the peace in conflict situations; and b) the international community to assist such endeavours by the OAU through financial, logistic, and capacity. ${ }^{42}$

\footnotetext{
${ }^{41}$ Corinne A.A. Packer, and Donald Rukare, 'The new African Union and its constitutive act,' American Journal of International Law 96:2, 2002, pp. 365-379; Ben Kioko, 'The right of intervention under the African Union's Constitutive Act: From non-interference to non-intervention,' International Review of the Red Cross 85:852, 2003, pp. 807-826; Ademola Abass, and Mashood A. Baderin, 'Towards effective collective security and human rights protection in Africa: An assessment of the Constitutive Act of the new African Union,' Netherlands International Law Review 49:1, 2002, pp. 1-38.

${ }^{42}$ International Panel of Eminent Personalities, 'Report on the 1994 genocide in Rwanda and surrounding events (selected sections),' International Legal Materials 40:1, 2001, pp. 141-236, p. 229.
} 
Studies on the transformation of the OAU to AU have revealed that article 4(h) was the exceptional outcome of African negotiations ${ }^{43}$ about empowering the latter with appropriate legal instruments grounding the legitimacy to use force for human rights protection. Thus, article 4(h) is the African subsidiary norm of the right to protect populations from atrocities, which demonstrates novel African originality, exceptional rule-making ability, and agency in international relations. The study that described the AU as a norm-entrepreneur is notable. ${ }^{44}$

Following the adoption of the R2P norm by the UN General Assembly in 2005, some studies have argued that article 4(h) localized or enshrined R2P; others have subsumed the African norm of the right to protect under R2P, and others interpreted article 4(h) as African agency in $\mathrm{R} 2 \mathrm{P} .{ }^{45}$ These studies assume that the AU is or should be a localizing agent in the global order, as reflected in Chapter VIII, which justifies subordinating the African subsidiary norm of the right to protect to the R2P rule. However, Thomas Weiss and Martin Welz have underlined the distinction, noting that article $4(\mathrm{~h})$ is 'Africa's home-grown version of the responsibility to protect. ${ }^{46}$

The parallel between the right to protect and $\mathrm{R} 2 \mathrm{P}$ is that both norms seek to prevent atrocities and protect human rights, but the differences are hugely relevant for understanding subsidiarity and African agency in peacemaking. The distinctions between R2P and the right

\footnotetext{
${ }^{43}$ Kioki, 'The right of intervention under the African Union's Constitutive Act'; Thomas Kwasi Tieku, 'Explaining the clash and accommodation of interests of major actors in the creation of the African Union,' African Affairs 103:411, 2004, pp. 249-67.

${ }^{44}$ Tim Murithi, 'The African Union as a norm entrepreneur: The limits of human protection and mass atrocities prevention,' Global Responsibility to Protect 8:2-3, 2016, pp. 227-248.

${ }^{45}$ Williams, 'From non-intervention to non-indifference'; Murithi, 'The responsibility to protect, as enshrined in article 4 of the Constitutive Act of the African Union'; Williams, 'The 'responsibility to protect'; Mwanasali, Musifiky, 'The African Union, the United Nations, and the responsibility to protect: towards an African intervention doctrine,' Global Responsibility to Protect 2:4, 2010, pp. 388-413; Kuwali and Viljoen, Africa and the responsibility to protect; Aning and Edu-Afful, 'African Agency in R2P'; Sarkin, Jeremy, 'Is the African Union's position on non-indifference making a difference? The implementation of the responsibility to protect (R2P) in Africa in theory and practice,' Journal of African Union Studies 5:1, 2016, pp. 5-37.

46 Thomas G. Weiss, and Martin Welz, 'The UN and the African Union in Mali and beyond: a shotgun wedding?' International Affairs 90:4, 2014, pp. 889-905, p. 891.
} 
to protect are many, the most remarkable being that international actors are contesting the former, and while it has remained essentially robust, the eventual outcome is yet to be determined ${ }^{47}$ Conversely, besides implementation challenges like the lack of capacity or will and clarifying the moment the Assembly's right to intervene becomes operational, ${ }^{48}$ there is no contest over the normative character of article 4(h). From the norm subsidiarity viewpoint, one pertinent consideration is the potential role of the UN Security Council in implementing the African norm of right to protect. Surely, Chapter VII of the UN Charter, which deals directly with actions to preserve international peace and security, places no constraints on measures or norms the Security Council can adopt in fulfilling the mandate and responsibility for global peace. The AU has offered leeway to the Security Council to draw on the subsidiary norm of the right to protect.

The AU policy compares article 4(h) to article 51 of the UN Charter, not R2P, as the only legitimate basis for the use of force in international affairs - the former deals with the protection of human rights and the latter with self-defence, thus:

With regard to the use of force, it is important to comply scrupulously with the provisions of Article 51 of the UN Charter, which authorise the use of force only in cases of legitimate self-defence. In addition, the Constitutive Act of the African Union, in its Article 4 (h), authorises intervention in grave circumstances such as genocide, war crimes and crimes against humanity.

\footnotetext{
${ }^{47}$ Cristina G. Badescu, and Thomas G. Weiss, 'Misrepresenting R2P and advancing norms: An alternative spiral?' International Studies Perspectives 11:4, 2010, pp. 354-374; Amitav Acharya, 'The R2P and norm diffusion: Towards a framework of norm circulation,' Global Responsibility to Protect 5:4, 2013, pp. 466-479; Natalie Zähringer, 'Norm evolution within and across the African Union and the United Nations: The Responsibility to Protect (R2P) as a contested norm,' South African Journal of International Affairs 20:2, 2013), pp. 187-205; Jennifer M. Welsh, 'Norm robustness and the responsibility to protect,' Journal of Global Security Studies 4:1, 2019, pp. 53-72.

48 Jakkie Cilliers, and Kathryn Sturman, 'The right intervention: Enforcement challenges for the African Union,' African Security Studies 11:3, 2002, pp. 28-39; Dan Kuwali, 'The conundrum of conditions for intervention under article 4 (h) of the African Union Act,' African Security Studies 17:4, 2008, pp. 89-111.
} 
Consequently, any recourse to force outside the framework of Article 51 of the

UN Charter and Article 4 (h) of the AU Constitutive Act, should be prohibited. ${ }^{49}$

In other words, the AU is offering the novel African norm on human rights protection to the international community, demonstrating that the Security Council can rely on the right to protect rule for the maintenance of international peace and security. Crucially, the policy shows norm exportation, a unique characteristic of subsidiary actors. So, the right to protect and R2P are parallel norms, as depicted in Figure I.

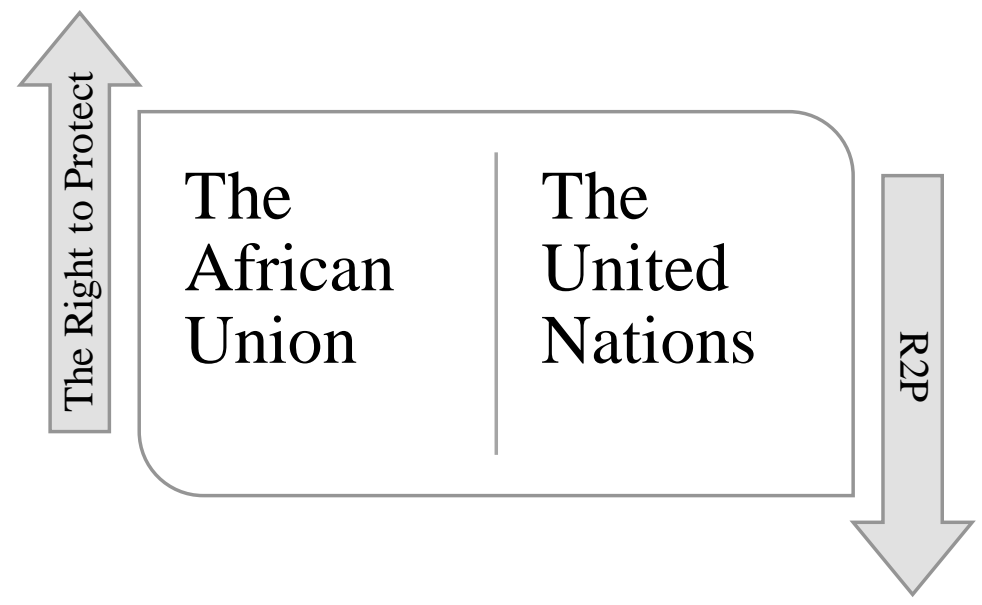

Figure I. Parallel Norms on Human Rights Protection

Meanwhile, the AU has rejected the R2P norm. The AU policy ties the R2P and sovereignty norms together, noting that 'It is important to reiterate the obligation of states to protect their citizens, but this should not be used as a pretext to undermine the sovereignty, independence and territorial integrity of states. ${ }^{, 50}$ This policy position indicates rejection of the R2P norm, not an endorsement, ${ }^{51}$ subordination, contestation, or localization. Indeed, the settled debate on

\footnotetext{
${ }^{49}$ African Union, 'The common African position on the proposed reform of the United Nations: "The Ezulwini Consensus",' Ext/EX.CL/2 (VII), 7-8 March 2005, p. 6. The Assembly has repeatedly endorsed the Ezulwini Consensus since 2006, including recently, see African Union, Assembly Decision, Assembly/AU/Dec.766 (XXXIII), 09-10 February 2020, para. 7.

${ }^{50}$ African Union, The Ezulwini Consensus, p. 6.

${ }^{51}$ Alex J. Bellamy, 'Whither the responsibility to protect? Humanitarian intervention and the 2005 World Summit,' Ethics \& International Affairs 20:2, 2006, pp. 143-169, pp. 157-162.
} 
the problem of humanitarian intervention and state sovereignty that led to the "the responsibility to protect' framing by the International Commission on Intervention and State Sovereignty (ICISS) validates norm subsidiarity and African agency in peacemaking.

The ICISS adopted the R2P language because of the "continuing fears about a "right to intervene" being formally acknowledged' in the international system. ${ }^{52}$ On the other hand, article 4(h) demonstrates Africa's formal recognition of the right to intervention for human protection. The purpose is to enable the AU to resolve conflicts more efficiently ${ }^{53}$ and create a firmer legitimate ground for the Assembly's primacy claim to the use of force for human rights protection. Still, and significantly, article 4(h) can serve the international community's objectives by underpinning the legitimacy of international action because Africa recognizes the right to protect civilians from atrocities. In this sense, the African subsidiary norm of the right to protect matters because it demonstrates substantial African agency in peacemaking.

\section{The RECs as Localizing Agents}

This subsection examines African policy instruments to establish that the RECs are localizing African norm-setting instruments including African norms, norm-implementing institutions, and global rules, specifically the $\mathrm{R} 2 \mathrm{P}$ principle. The purpose is to underline the differences in normative behaviour between the AU and African subregional agencies. It selects two out of the eight existing RECs as examples: IGAD and ECOWAS. To illustrate the RECs' inclination to localize international norms, the analysis focuses on ECOWAS and highlights the subregional organization's effort to align its human security priorities to the right

\footnotetext{
52 International Commission on Intervention and State Sovereignty, The Responsibility to Protect (Ottawa: International Development Research Centre, 2001), p. 11.

${ }^{53}$ Kioki, 'The right of intervention under the Constitutive Act of the African Union,' p. 817.
} 
to protect and R2P norms, indicating the willingness to accept or modify global and regional rules. Essentially, ECOWAS engages in norm localization, unlike the AU.

The UN, the AU, and the RECs have embraced the principle of subsidiarity in peacemaking. However, the AU and the RECs have accepted division of labour as the guiding principle, and the RECs recognize the AU's primacy. Particularly, article IV of the Memorandum of Understanding on cooperation between the AU and the RECs in peacemaking notes 'the primary responsibility of the [African] Union' in maintaining and promoting 'peace, security, and stability,' and underlines 'the principles of subsidiarity, complementarity, and comparative advantage.' Also, the APSA assessment study emphasizes subsidiarity and 'division of labour.' Equally, the APSA Roadmap embraces subsidiarity, acknowledging that the lack of a shared understanding of its implications requires clarification. In that regard, the Assembly adopted Paul Kagame's recommendations on institutional reforms of the AU, which highlighted that 'There should be a clear division of labour in line with the principle of subsidiarity.' Finally, article 3 of the Protocol on Relations between the AU and the RECs provides that the objective is to 'promote cooperation in all fields and sectors in line with the principle of subsidiarity and complementarity. ${ }^{54}$

Paul Kagame's recommendations on institutional reforms of the AU provided insights into the current thinking about the principle of subsidiarity in peacemaking on the continent. Pertinently, adopting Kagame's report, the Assembly decided that the 'African Union should focus on a fewer number of priority areas, which are by nature continental in scope, such as

\footnotetext{
${ }^{54}$ African Union, 'Memorandum of Understanding'; African Union, Moving Africa forward: African peace and security architecture 2010 assessment study (Addis Ababa: African Union Commission 2010), p. 196; African Union, African peace and security architecture: APSA roadmap 2016-2020 (Addis Ababa: African Union Commission, Peace and Security Department, 2015), pp. 54-55; African Union, Assembly Decision, Assembly/AU/Dec.635(XXVIII), annex, 30-31 January 2017, paras. 5, A; African Union, Draft revised protocol on relations between the African Union and the Regional Economic Communities, EX.CL/1221(XXXVI)iii, 0607 February 2020, adopted by the Assembly Decision, Assembly/AU/Dec. 767(XXXIII), 09-10 February 2020, para. 5.
} 
political affairs, peace and security, economic integration (including the Continental Free Trade Area), and Africa's global representation and voice.' The decision coincides with the AU Commission mandate to formulate peace and security rules and coordinate the RECs' programs to align with African norms and institutions. Specifically, article 8 of the Protocol on Relations stipulates that the Coordination Committee, including the Assembly Bureau, the AU Commission Chairperson, and the RECs' CEOs, is 'responsible for coordinating and harmonising the policies ... in the field of peace and security. ${ }^{, 55}$

The Assembly has noted the progress on outlining the division of labour on the 'sectors of ... Political Affairs and Peace and Security.' The Assembly plans to adopt the framework document on division labour at 'the 35th Ordinary Session ... in February 2022.' 56 The significance is that the AU and the RECs have accepted division of labour as the guiding principle of subsidiarity in peacemaking. The AU retains primacy and increasingly declares that the RECs 'serve as its building blocks' for Africa's norms and institutions or, as the AU Chairperson for 2020, Cyril Ramaphosa put it, 'It is imperative that we strengthen the RECs as building-blocks for Africa's continental integration.' 57

As the basic units of integration and peacemaking, the RECs are required to localize African norm-setting instruments and norm-implementing institutions. Indeed, the Assembly

\footnotetext{
55 African Union, Assembly Decision, Assembly/AU/Dec.635(XXVIII), annex, 30-31 January 2017, para. A; African Union, Draft Revised Protocol on Relations between the African Union and the Regional Economic Communities, EX.CL/1221(XXXVI)iii, 06-07 February 2020.

56 African Union, Assembly Decision, Assembly/AU/Dec.801(XXXIV), 6-7 February 2021, para. 5; African Union, 'Communiqué of the teleconference meeting of the Bureau of the Assembly of African Union Heads of State and Government,' Press Release, 8 July 2021, p. 4, <https://au.int/en/pressreleases/20210708/communiquebureau-assembly-held-24-june-2021>

57 African Union, African Union handbook: A guide for those working with and within the African Union (Addis Ababa; Wellington: African Union Commission; New Zealand Ministry of Foreign Affairs and Trade/Manatū Aorere, 2021), p. 152; African Union, 'African Union 2nd mid-year coordination meeting closes with a resolve to strengthen collaboration between the AU, RECs, RMs, the member states, and other continental institutions, in line with the principle of subsidiarity, Press Release, 22 October 2020, <https://au.int/en/pressreleases/20201022/african-union-2nd-mid-year-coordination-meeting-closes-resolvestrengthen>
} 
had urged 'the RECs to promote African Shared Values [on] democracy, governance and popular participation. ${ }^{58}$ Table 2 illustrates ECOWAS and IGAD localization efforts.

Table 2. Localization of African Norm-setting Instruments and Norm-implementing Institutions

Institutions/Instruments

\begin{tabular}{|c|c|c|}
\hline Panel of the Wise & Council of Elders or the Wise & $\begin{array}{c}\text { Roster of Experienced } \\
\text { Diplomats and Respected } \\
\text { Public Figures }\end{array}$ \\
\hline Peace and Security Council & $\begin{array}{c}\text { Mediation and Security } \\
\text { Council }\end{array}$ & Council of Ministers \\
\hline $\begin{array}{c}\text { Continental Early Warning } \\
\text { System }\end{array}$ & $\begin{array}{c}\text { Regional Peace and Security } \\
\text { Observation System or Early } \\
\text { Warning System }\end{array}$ & $\begin{array}{l}\text { Conflict Early Warning and } \\
\text { Response Mechanism }\end{array}$ \\
\hline Peace Fund & $\begin{array}{l}\text { Peace Fund, replaced the } \\
\text { Community Levy }\end{array}$ & $\begin{array}{c}\text { Special Drought Fund/Rapid } \\
\text { Response Fund/ Mediation } \\
\text { Fund }\end{array}$ \\
\hline African Standby Force & ECOWAS Standby Force & Eastern African Standby Force \\
\hline Norm-setting Instruments & $\begin{array}{l}\text { Protocol on Democracy and } \\
\text { Good Governance, } \\
\text { supplementary to the Protocol } \\
\text { Relating to the Mechanism for } \\
\text { Conflict Prevention, } \\
\text { Management, Resolution, } \\
\text { Peacekeeping and Security }\end{array}$ & $\begin{array}{l}\text { Protocol on Democracy, } \\
\text { Governance and Election }\end{array}$ \\
\hline
\end{tabular}

Although ECOWAS and IGAD mimic African norm-setting instruments and normimplementing institutions, they are not 'wholesale' localizing agents in the sense that they take and adapt regional and global norms, rules, and institutions, which explain the occasional disagreements in peacemaking strategies. ${ }^{59}$ The ECOWAS policy on the use of force for human

\footnotetext{
${ }^{58}$ African Union, Assembly Declaration, Assembly/AU/Decl. 1(XVI), 30-31 January 2011, para. 10.

${ }^{59}$ For a helpful analysis of the cases where the UN, the AU, and the RECs have disagreed over operational approaches to peacemaking, see Nathan, 'Will the lowest be first?'
} 
rights protection illustrates the localization of the African subsidiary norm of the right to protect and the R2P principle.

ECOWAS, the Right to Protect, and R2P

Although the AU represents Africa's voice in global diplomacy and external relations, the RECs exercise agency in international politics and can conduct foreign affairs with nonAfrican organizations, including the UN, under Chapter VIII of the UN Charter. Article 25 of the Protocol on Relations between the AU and the RECs deals with the latter's 'external relations' and provides that

a regional economic community may enter into co-operation agreements with other international organizations or with third countries provided that such agreements do not conflict with the objectives of the Constitutive Act, the Abuja Treaty and the treaties. ${ }^{60}$

ECOWAS, one of the more active RECs, has explicitly defined its relations with the UN and AU in peacemaking. Article 40 of the ECOWAS Conflict Prevention Framework (ECPF) notes that 'The three bodies [the United Nations, the African Union, and ECOWAS] cooperate on the issues of peace and security on the principles of subsidiarity and complementarity in accordance with the provisions of Chapter VIII of the UN Charter. ${ }^{961}$ Article 41 of the ECPF shows that ECOWAS takes and modifies or localizes the right to protect and R2P norms:

ECOWAS is imbued with the necessary supranational powers (acting on-behalf of and in conjunction with Member States, AU and UN), as well as the legitimacy to intervene to protect human security in three distinct ways, namely:

\footnotetext{
${ }^{60}$ African Union, 'Draft revised protocol on relations between the African Union and the Regional Economic Communities.'

${ }^{61}$ ECOWAS, The conflict prevention framework, Regulation MSC/REG.1/01/08, 16 January 2008.
} 
a. the responsibility to prevent; b. the responsibility to react; and c. the responsibility to rebuild.

Clearly, ECOWAS accepts that some aspects of its power to intervene come from the AU and the UN. But ECOWAS' agency lies in the 'legitimacy to intervene to protect human security,' indicating that the subregional organization can act to protect human rights inside or outside AU and UN rules. Notably, ECOWAS's formulation parallels the right to protect and R2P norms but falls short of adopting article 4(h) and R2P as outlined in the General Assembly resolution but embraces the ICISS's construction. ${ }^{62}$

Article 41 framing underlines the importance ECOWAS places on the legitimacy of the use of force to protect human rights, a subject of equal significance in the African subsidiary norm of the right to protect. At the same time, ECOWAS's policy behaviour shows the readiness to accept and modify global rules to fit its human security or people-centred security governance objectives in peacemaking. ${ }^{63}$ The policy action demonstrates norm localization. In other words, ECOWAS is a localizing actor in peacemaking and the global order, as envisioned in Chapter VIII of the UN Charter. The significance of the determination that ECOWAS is a localizer is that it sharpens the understanding of the AU as the subsidiary actor and refines the differences in African agencies in peacemaking.

\section{Conclusion}

\footnotetext{
${ }^{62}$ United Nations, World Summit Outcome, General Assembly Resolution, A/RES/60/1, 24 October 2005, paras. 138-40; International Commission on Intervention and State Sovereignty, The Responsibility to Protect, chaps. 35.

${ }^{63}$ Article 4 of the ECPF notes that as "the new ECOWAS Strategic Vision to transform the region from an 'ECOWAS of States' into an 'ECOWAS of the Peoples', the tensions between sovereignty and supranationality, and between regime security and human security, shall be progressively resolved in favor of supranationality and human security respectively".'
} 
African agency, through African regional organizations, in peacemaking has become critical in managing and neutralizing contemporary threats to international peace and security - from fighting terrorism to protecting human rights and promoting democracy. African norms of the right to protect and the Heads of State and Government immunity are crucial for understanding subsidiarity in peacemaking and African agency in global politics and, therefore, matter. This article contributes to knowledge in major ways, 1) African agency in international politics and 2) subsidiarity in peacemaking.

First, this article contributes to the scholarship on African agency in international relations. African norms are a unique component of African agency, and the subordination of the right to protect to the $\mathrm{R} 2 \mathrm{P}$ principle and the immunity norm to nonimpunity overlooks Africa's original initiatives in global peacemaking endeavours. In many ways, studies that subsume the African subsidiary norm of the right to protect under R2P effectively deny African agency: Africa's initiative and decision-making competence to create unique norms, rules, and institutions for human rights protection. They also deny the international community the opportunity to learn and understand what makes African subsidiary norms exceptional and enjoy the benefits of the more robust and less contested norm. Likewise, the Heads of State and Government immunity norm underpins the African agency and matters. The immunity norm, although backward-looking, contributes to a better understanding of norm subsidiarity in the international order and peacemaking. It enriches our knowledge, empirically, of how subsidiary actors in the international system make rules to preserve their independence and manage fears of external domination. The most significant consequence of the norm-setting instrument, the Malabo Protocol, is that it sets the standard for regional initiatives for atrocity prevention through investigations and prosecutions. When operational, the African Court becomes a crucial component of the global struggle to prevent genocide, war crimes, crimes against humanity, and ethnic cleansing, as well other crimes that threaten international peace 
and security, such as corruption and money laundering. Indeed, the Malabo Protocol established the pioneering norms for dealing with these crimes and therefore matter.

Second, this article contributes to understanding the challenges facing the UN, the AU, and the RECs in applying the principle of subsidiarity in peacemaking. Indeed, as the correlation between regional capacities and peacemaking initiatives becomes more tangible, the impact of African norms will become more vivid, and will likely lead to frequent quarrels between the international community, as represented by UN Security Council, and the AU Assembly over whose norms matter and take primacy. However, disagreements over norm priority are not inevitable. A better understanding of the African agency will inform a more productive strategic and pragmatic dialogue about applying the principle of subsidiarity. The knowledge advanced in this study that the AU is a subsidiary actor, not a localizer as the framers of and some scholarship on Chapter VIII of the UN Charter anticipated, enlightens the conversation. The international community and other African partners, especially the European Union, face the challenge of persuading the AU to become a double agent. By a double agent, I mean the possibility that the AU agrees to implement, not localize uncomfortable international norms occasionally.

The notion of the double agency may seem challenging for a subsidiary agent whose norms essentially underpin the desire to retain autonomy and counter external control and domination concerns. Still, the AU has demonstrated a remarkable degree of normative flexibility, making exploring double agency rational. ${ }^{64}$ The AU's ongoing effort to modify the African norm on unconstitutional changes to government, which had been one of the few near sacrosanct African norms, is demonstrative. The Lomé Declaration for an OAU Response to

\footnotetext{
${ }^{64}$ Notably, a study on statebuilding and stabilization operations in Africa found ambiguities in policy formulations and actions within the AU, which demonstrates flexibility, see Obinna, F. Ifediora, 'Hybrid regional order: The role of the African Union in statebuilding and stabilization operations in Africa,' Journal of International Peacekeeping 20, 3-4, 2016, pp. 363-394.
} 
Unconstitutional Changes to Government and the African Charter on Democracy, Elections, and Governance prohibit coup d'états and ban perpetrators from participating in subsequent government or elections. However, following the widespread protests in North Africa between 2010 and 2011 that led to the resignation and the military removal of a few Heads of State and Government, the AU has altered the norm to accommodate the people's aspirations for freedom, security, human rights, and good governance.

In a rare open session, the Peace and Security Council invited African civil society groups to address the implications of 'popular uprisings in Africa.' They 'expressed understanding' for irregular changes to government 'In circumstances where governments fail to fulfill their responsibilities, are oppressive and systematically abuse human rights or commit other grave acts and citizens are denied lawful options,' and called for a 'review of existing normative frameworks' involving

appropriate refinement of the definition of unconstitutional changes of government, in light of the evolving challenges facing the continent, notably those related to popular uprisings against oppressive systems, taking into account all relevant parameters. ${ }^{65}$

The AU Assembly and Peace and Security Council adopted the recommendations of the AU High-Level Panel for Egypt that studied the question of popular uprisings and specified conditions under which the AU should accept unconstitutional changes to government, which involves:

(a) the descent of the government into total authoritarianism to the point of forfeiting its legitimacy; (b) the absence or total ineffectiveness of constitutional processes for effecting change of government; (c) popularity of the uprisings in the sense of attracting significant portion of the population and involving people

\footnotetext{
${ }^{65}$ African Union, 'Unconstitutional changes of governments and popular uprisings in Africa - challenges and lessons learnt,' Press Statement, PSC/PR/BR. (CDXXXII), 29 April 2014, pp. 2, 3-4.
} 
from all walks of life and ideological persuasions; (d) the absence of involvement of the military in removing the government; (e) peacefulness of the popular protests. ${ }^{66}$

What is emerging is the new African norm that the people can change their government through unconstitutional methods if the government acts irresponsibly. Although the Peace and Security Council noted that the lifting of sanctions in the case of Egypt 'does not constitute a precedent in terms of adherence to norms 'which stipulate that perpetrators of unconstitutional changes of Governments cannot participate in the elections held to restore constitutional order, ${ }^{67}$ it reacted cautiously to similar events in Zimbabwe, Mali, Sudan, and Guinea. The case of Egypt is seemingly not an exception; it is becoming the new African norm. This normative adaptability to popular demands shows that the AU can change or modify ostensibly firmly rooted norms.

The AU's normative flexibility implies that the Assembly and Peace and Security Council will likely revise the Heads of State and Government immunity under the right circumstances. The African people involving civil society groups convinced the AU to change a norm that previously favoured regime security or stability. In some ways, triggers and catalysts for such norm-altering conversations may have external beginnings through strategic dialogue and engagement with the Assembly and the Peace and Security Council. Specifically, the UN Security Council could explore its role in implementing the right to protect norm, so approving members may turn to the AU when the P5 deadlocks around the R2P principle. Equally, the ICC Prosecutor may undertake similar exchanges with the Peace and Security

\footnotetext{
${ }^{66}$ African Union, Assembly Decision, Assembly/AU/Dec.536 (XXIII), 26-27 June 2014, para. 8; African Union, Peace and Security Communiqué, PSC/PR/COMM.2 (CDXLII), 17 June 2014, para. 7; African Union, Final Report of the African Union High-Level Panel for Egypt, PSC/AHG/4. (CDXVI), 17 June 2014, para. 83.

67 African Union, Peace and Security Council Communiqué, PSC/PR/COMM.2 (CDXLII), 17 June 2014, para. 8.
} 
Council and the African Court Prosecutor when inaugurated regarding the Malabo Protocol and the Rome Statute.

This study's significance for future dialogue between the UN, the EU, and African regional organizations is appreciating that the problem of utilizing the principle of subsidiarity is essentially about the contest over the primacy of African subsidiary norms, which we now know, are extremely accommodating in appropriate circumstances. This article has shown that the AU is not the localizing agent as Chapter VIII prescribed. Instead, the AU is a subsidiary agent in the current global order, so expectations and conversations about how the AU implements external norms need to take a more persuasive turn. The African people convinced the AU to change a significant norm on regime security and stability. In that case, the international community can do the same, but it requires the Security Council and other global actors to become more influential and compelling with their ideas and rules. Ultimately, an unambiguous division of labour between the Security Council and the AU will promote better sequencing of African and international norms in peacemaking. 